\title{
Yrittäjyysminän ääriviivoja hahmottamassa
}

\section{Pekka Kuusela, YTT, yliopistonlehtori, Itä-Suomen yliopisto}

Bröckling, Ulrich: The Entrepreneurial Self. Fabricating a New Type of Subject. Sage, London, 2016.

Saksalaisen kulttuurisosiologin Ulrich Bröcklingin teos on erittely modernin yksilön minuuden rakentumisen muutoksesta, jota hän nimittää yrittäjyysminäksi. Teos liittyy kiinteästi toisaalta neoliberalismia kriittisesti erittelevän tutkimuksen perinteeseen, toisaalta Foucault'n tutkimusten synnyttämään subjektivoitumisen uudenlaisten muotojen kartoitukseen. Kuten Bröckling itse teoksensa esipuheessa toteaa, yrittäjyys ei ole vain ammatti tai kutsumus, vaan kokonainen tapa ymmärtää oman olemassaolon tarkoitus ja työstää omaa minää yrittäjänä olemisen toteutumiseksi. Laajassa mielessä kyse ei ole siis yksistään osakkeenomistajan tai liikemaailman ihmisen toimintatavoista, sillä Bröckling tarkoittaa yrittäjyysminällä tiettyä subjektiivisesti rakentunutta ymmärrystä siitä, että elämässä onnistuminen on viime kädessä itsestä kiinni ja että ihmisen tulee mitata ja arvioida onnistumistaan jatkuvasti itse. Tässä suhteessa yrittäjyysminässä on kyse tietynlaisesta jatkuvasta pyrkimyksestä olla "hyvän yrittäjän" normatiivisen ideaalin kaltainen olento, joka on kuitenkin ikään kuin ihmiselle itselleen kaukainen, jatkuvasti pakeneva saavuttamaton ihanne.

Bröckling luotaa kirjassaan yleisellä tasolla yrittäjyysminän syntyä historiallisena ilmiönä, josta on muodostunut kulttuurisesti myöhäismoderneissa yhteiskunnissa siis minuuden tuottamisen hallitseva ideologinen muoto. Kirjan yleinen rakenne on se, että Bröckling kartoittaa alussa käsitteellisesti yrittäjyysminän muodostumisen luonnetta ja konteksteja. Sen jälkeen hän siirtyy erittelemään teoksensa ensimmäisessä osassa yrittäjyysminän rationaalisuutta, johon liittyy neoliberalistisen ideologian muunnelmat, 
yrittäjän erilaisten tehtävien tarkastelu sekä sopimuksiin perustuvan maailman hahmottaminen. Toinen osa keskittyy puolestaan enemmän yrittäjyysminän strategioiden ja ohjelmien selvittelyyn. Kirjan lopussa tehdään vielä yhteenvetoa keskeisistä teemoista.

Kirja on ytimeltään erittely neoliberalistisen ajattelun ideologisesta vaikutuksesta yksilön subjektiiviseen itsemäärittelyyn ja toimintaan. Ideologisten analyysien tyylin mukaisesti tarkastelu lähtee talouden muutoksista ja neoliberalismin vaikutuksen laajentumisesta 1970-luvun lopulla, joka on luonut tarpeen yrittäjyysminän rakentumiselle. Bröckling määrittelee yrittäjyysminää negaatioiden kautta. Kyse ei ole keskimääräisestä persoonallisuudesta, uudesta sosiaalityypistä tai luonnenaamiosta, vaan enemmänkin ei-havaittavasta empiirisestä itsenäisestä kokonaisuudesta jatkuvassa tulemisensa prosessissa tai keskeneräisestä projektista. Tällaisena sillä voidaan ymmärtää normatiivista mallia ihmisestä toimijana sekä kokoelmaa erilaisia minuusteknologioita ja sosiaalisia teknologioita, joiden tavoitteena on organisoida elämä yrittäjyyden muotoon. Yhteiskunnallisen muutoksen rakenteellisen syyn Bröckling paikantaa siihen, että talous ei enää palvele yhteiskuntaa, vaan yhteiskunta ja sen instituutiot mukautetaan talouden vaatimuksiin. Siinä on hänen mukaansa neoliberalismin kova ydin. Näin markkinaliberalismiin perustuva taloudellinen eetos tuottaa toisin sanoen ihmisille uudenlaisen ymmärryksen itsestään ja elämän tarkoituksesta.

The Entrepreneurial Self -kirja sisältää kiinnostavia pohdintoja teollisen yhteiskunnan muutoksesta, neoliberalismin historiasta ja esimerkiksi talouden rationaalisuuden synnystä. Aiempi homo economicus -käsitys (Smith, Hume, Ferguson) korosti ihmisen luonnollista taipumusta toimia rationaalisesti talouden alueella, elleivät poliittiset tekijät häiritse tätä pyrkimystä. Uudempi neoliberaali käsitys korostaa enemmän valtion roolia yrittäjyysminän jatkuvassa uudelleenluomisessa ja aktivoinnissa. Bröckling viittaa erityisesti hallintamieltä tarkastelleisiin tutkijoihin ja liike-elämän asiantuntijoihin, jotka ovat olleet luomassa uudenlaista konstruktiota yrittäjyydestä ja yrityksistä. Uuden diskurssin juuret ovat 1970-luvun lopulla ja 1980-luvun alussa, mutta täyteen lentoon markkinaliberaali yrittäjyysdiskurssi pääsi 1990-luvulla. Bröckling viittaa tässä erityisesti Saksaan, mutta yrittäjyysdiskurssin hallitseva asema on ollut ilmeiseksi kaikissa myöhäismoderneissa yhteiskunnissa viimeisten parin vuosikymmenen kuluessa. 
Kirjansa ensimmäisessä osassa Bröckling tarkastelee tarkemmin erilaisia neoliberalismin suuntauksia ja käsityksiä markkinoiden toiminnasta. Olennainen puoli tässä tarkastelussa on se, että markkinamekanismia ja markkinoita pidetään etuoikeutettuna sosiaalisen integraation välineenä. Koko yrittäjyysminuuden ja miksei Foucault'n neoliberalismia koskevien tarkastelujen ydin on siinä, että markkinamekanismi tunkeutuu kaikkialle sosiaalisiin suhteisiin, koskivatpa ne sitten työtä, sosiaalipalveluita, ystävyyttä, johtamista tai vaikkapa hoivaa. Bröckling erittelee tarkemmin erityisesti Foucault'n kiinnostuksen kohteena ollutta saksalaista ordoliberalismia ja amerikkalaista inhimillisen pääoman teoriaa. Neoliberaalin taloustieteen tutkijoiden esittämien tulkintojen mukaan 1930-luvun talouslaman syy ei ollut markkinoissa, vaan pikemminkin markkinoiden epätäydellisessä toiminnassa. Ordoliberaalit pyrkivät puolestaan turvaamaan kilpailun institutionaalisen pohjan, kun kilpailu nähdään inhimillisen pääoman teoriassa ihmisen käyttäytymistä ohjaavaksi voimaksi. Bröcklingin analyysin tarkoituksena on tuoda esille tässä mielessä neoliberalistisen taloustieteen erilaiset muunnelmat.

Tehtävien tai funktioiden kuvauksessa yrittäjän toimintaa eritellään niiden tehtävien kautta, mitä yrittäjällä on edessä markkinoilla toimiessaan objektiivisina tosiasioina. Bröckling toisin sanoen tarkastelee taloustieteellisten teorioiden valossa sitä, millaisia tehtäviä yrittäjyyteen liittyy pelkän rationaalisuuden tai voiton tavoittelun lisäksi. Tällaisiksi tehtäviksi ovat lähinnä neoliberaalit taloustieteilijät nähneet spekulaattorin, innovaattorin, riskinottajan ja koordinaattorin. Ajatuksena on se, että yrittäjän tehtäväkuvaa ymmärtääkseen on nähtävä hänen toimintansa laajemmin markkinoiden toiminnan konteksteissa. Tehtävät luovat yrittäjälle tunnusomaisen toimintatavan, joka erottaa hänet muista inhimillisen toiminnan muodoista. Kyse ei ole sisäisistä ominaisuuksista, vaan enemmänkin vaatimuksista, jotka liittyvät sopimusten mukaan toimiviin markkinoihin. Tehtäviä ei voi myöskään erottaa kovin helposti toisistaan, vaan ne liittyvät toisiinsa myös neoliberalismia edustavien talousteoreetikoiden ajattelussa. Tällaisina ne luovat kuvan siitä, mitä on menestyksellinen yrittäjyys ja miten sitä pitää tavoitella eettisessä mielessä, kuten Kantin määritelmä valistuksesta itseaiheutetusta alaikäisyydestä irtipääsemisenä.

Kirjan toinen osa on laaja katsaus siihen, miten yrittäjyyttä voidaan tarkastella muuten kuin talousteorioiden valossa. Avainkäsitteinä tuodaan esille neljä puolta, jotka ovat luovuus, valtaistuminen (empowerment), laatu ja projektit. 
Nämä tarjoavat taloustieteellisten teorioiden ohella tärkeitä näkökulmia yrittäjyyden erilaisiin puoliin. Luovuus voidaan nähdä kyvyksi tunnistaa ja tarttua voiton tekemisen mahdollisuuksiin, ja sitä voidaan tarkastella psykologisesti sosiaalisena tavoitteena ja opittavana taitona. Yrittäjyysminän aktiivisuus ja itsenäisyys liittyy valtaistumiseen, kun laadun olennainen puoli kytkeytyy inhimillisen pääoman myymiseen markkinoilla. Projekteissa toimimisen kyky on viimein sidoksissa siihen, että työtä tehdään monimuotoisissa projektiorganisaatioissa, joka edellyttävät kykyjä toimia tiimeissä. Tällaisina mainitut puolet eivät liity suoranaisesti markkinamekanismeihin, vaan ne ovat enemmän yrittäjyyteen liittyviä psykologis-sosiaalisia tekijöitä, joita työelämä ja kulttuuri edellyttävät ihmiseltä nykyaikana.

Kirjan lopun huomiot tuovat esille vaihtoehtoisia itsemäärittelyn kehyksiä yrittäjyysminälle. Bröckling käsittelee erityisesti masentuneisuutta, ironisuutta ja passiivista vastarintaa keinoina käsitellä yrittäjyyden tuottamia normatiivisia paineita. Niistä mikään ei ole sinänsä riittävä taktinen keino minuuden vapauttamiseksi markkinoista. Masentuneisuus, uupumus ja addiktiot edustavat yrittäjyysminän negatiivista puolta: kaikki ilmaisevat ihmisen kyvyttömyyttä kestää paineita ja tuottaa itselleen yrittäjyyden mukaista minuutta. Kun aiemmin terapiassa oli mahdollista käsitellä omaa riittämättömyyttä ja muistella menneitä, vastuun sysääminen ihmisille itselleen tuottaa seurauksenaan depressiolääkkeet, jotka auttavat tulemaan toimeen paineiden kanssa ja pitävät minän optimoinnin muistissa. Vastaavasti positiivisina keinoina ironia ja passiivinen vastarinta edustavat pyrkimystä ottaa etäisyyttä yrittäjyysminän vaatimuksiin. Jos paineille voi nauraa tai vastustaa niitä, pääsee irti voimakentän otteesta. Mitään laajempaa poliittista aktivismia Bröcklingin käsittelemiin vaihtoehtoisiin elämäntavan kokeiluihin ei ole liittynyt, ja hänen käsittelemänsä esimerkit ovat Saksasta (Iloiset työttömät, Die Glücklichen Arbeitlosen ja Joutilaisuusgangsterit, Müssiggängster).

Kenelle Bröckling on sitten kirjoittanut kirjansa ja mikä sen tarkoitus on? Kuten hän teoksensa alkupuolella mainitsee, se on syntynyt artikkeleiden ohessa erittelynä yrittäjyysminän luonteesta. Yleisessä mielessä yrittäjyys pyritään kirjassa kytkemään tavanomaista pidemmälle taloustieteellisiin, psykologisiin ja sosiaalisiin teorioihin. Tässä mielessä Bröcklingin analyysi kytkee taloustieteet huomattavasti pidemmälle neoliberalismia ja yrittäjyyttä koskevaan pohdintaan kuin aiempi tutkimus tai uudemmat analyysit, kuten David 
Harvey (2005) tai Jim McGuigan (2016). Toisaalta kun kyseessä on kuitenkin aika yleisellä tasolla liikkuva pohdinta yrittäjyysminästä, tämä tarkoittaa myös käytännössä sitä, että kirja ei pyri olemaan sellaisenaan uudenlainen teoreettinen tulkinta yrittäjyyteen liittyvistä puolista. Saksalaiseen perinteeseen pohjautuva esityksenä kirjassa on paljon yleistä teoreettista ja kriittistä tarkastelua aikakauden tilanteesta, mutta varmasti sellaistakin juuri kaivataan yrittäjyysminän ja neoliberalismin tutkimuksessa. Kirjaa voi siis suositella kaikille, jotka ovat kiinnostuneita syventämään näkemystään nykymaailman menosta ja tulevaisuuden suuntaviivoista. Varmaan kirjan lukemisen jälkeen ymmärtää paremmin myös sitä, miksi uusi hallitus tekee sellaista politiikkaa kuin tekee. Neoliberaalissa markkinavapaudessa ei oikein muita vaihtoehtoja juuri nähdä mahdolliseksi kuin yrittäjyysminän mukaisen toiminnan määrittely ideaaliksi ja hyvän elämän mittapuuksi.

\section{Lähteet}

Harvey, David. 2005. A Brief History of Neoliberalism. Oxford: Oxford University Press.

McGuigan, Jim. 2016. Neoliberal Culture. New York: Palgrave McMillan. 